\title{
Isolation and identification of bacteriocin- producing lactic acid bacteria from plants in Mount Makiling Forest Reserve, Philippines
}

\author{
Emil C. Lat ${ }^{1}$, Francisco B. Elegado ${ }^{1 *}$ and Ida F. Dalmacio ${ }^{2}$
}

\begin{abstract}
Sixty-three lactic acid bacteria (LAB) were isolated from trapped or stagnated water in parts of 14 different plant species in Mount Makiling Forest Reserve, Philippines and were screened for bacteriocin production. Thirteen of these isolates were found antagonistic to different indicator bacterial strains through direct assay. However, after screening of the pH-neutralized culture supernatant using 'spot-on-lawn' method against Enterococcus faecium 79 as the indicator strain, only one isolate, designated as $M L 258$, was confirmed to be bacteriocinproducer. Its crude extract of bacteriocin exhibited inhibitory activity against $E$. faecium and Lactobacillus acidophilus. The isolate was characterized and found to be gram-positive short rods that occurred in pairs, singly or in chains, catalase negative, microaerophilic, non-motile, non-spore forming and exhibited a heterofermentative type of fermentation. This isolate was obtained from fern (Microsorum longissimus) and was identified as Carnobacterium piscicola using API $50 \mathrm{CHL}$ kit with good identification of $98 \%$. However, the 16S rRNA gene sequencing and homology search from NCBI database using the BLAST program showed that the isolate is $93-95 \%$ similar with Carnobacterium maltaromaticum. On the other hand, phylogenetic analysis using MEGA 5 software that constructed a neighbor joining tree thru bootstrap method revealed that this isolate showed more similarity with Enterococcus sp.
\end{abstract}

Keywords: Lactic acid bacteria, bacteriocin, Carnobacterium piscicola, Carnobacterium maltaromaticum, Mount Makiling, 16S rRNA

'National Institute of Molecular Biology and Biotechnology

${ }^{2}$ Institute of Biological Sciences, College of Arts and Sciences, University of the Philippines Los Baños, College, Laguna, Philippines

*Corresponding Author. Address: National Institute of Molecular Biology and Biotechnology; Email: fbelegado@up.edu.ph

DOI:10.32945/atr4111.2019 
Lat, Elegado \& Dalmacio

\section{INTRODUCTION}

Lactic acid bacteria (LAB) consist of relatively diverse groups of bacteria, related by a number of typical metabolic and physiological features. In recent taxonomic revisions, this group is composed of at least ten genera, which include Aerococcus, Carnobacterium, Enterococcus, Lactobacillus, Lactococcus, Leuconostoc, Pediococcus, Streptococcus, Tetragenococcus, and Vagococcus (Axelsson 2004, Halász 2009). They are ubiquitous in nature, normally found in man, animal and plant materials (Narvhus \& Axelsson 2003). For centuries, they have been used in preparing and improving storage or shelf-life of various foods; but during the ancient times, their role in the preservation of food was not yet understood. Today, they have become so popular and used mainly as starter cultures in a variety of food fermentation that not only preserve but also give the food desirable characteristics such as flavor and texture (Yerlikaya 2014).

LAB have become a topic of many studies and researches because of their many potential applications. In food system, their importance is related to their potential use as a biopreservation tool. This is because many LAB were found to produce various types of antimicrobial compounds which have bactericidal effects and can efficiently inhibit growth of both spoilage and food-borne pathogens such as Bacillus, Enterococcus, Listeria, Clostridium and Staphylococcus. The mechanisms responsible for this inhibition could be brought about by the formation of organic acids, enzymes, and bacteriocin that contribute to the natural preservation of food (Fijan 2016). Bacteriocins, unlike antibiotics, restrict their activity to strains closely related or strains of the same species (Zacharof \& Lovitt 2012). The specificity of the bacteriocin ensures that harmless bacteria do not get killed. Furthermore, bacteriocins are ribosomally synthesized thus easily degraded by proteolytic enzymes, making them safer for human consumption (Woraprayote et al 2016, Yang et al 2014).

Bacteriocin production among LAB species is strain-dependent. In fact, particular LAB strains of several species such as Lactobacillus, Lactococcus, Pediococcus, Leuconostoc and Carnobacterium were observed to produce bacteriocin (Perez et al 2015). Lactococcus lactis, for instance, produces the best known and extensively studied bacteriocin Nisin A, which is approved for use as food additive by the World Health Organization (WHO) and currently being used for food preservation in more than 50 countries. The continuous search is directed towards the goal of discovering new bacteriocin which may be a good candidate for various industrial applications. Pediocin-like bacteriocins or Class Ila bacteriocins, for instance, have been receiving great attention because of their properties that have wide applications particularly in the food industry (Ennahar et al 2000). At present, some bacteriocins are also gaining approval on a per country basis.

In the Philippines, research on bacteriocin is not yet extensively investigated. Only a few had conducted studies on bacteriocin and bacteriocin-producing strains which were mostly isolated from indigenous fermented foods and beverages (Banaay et al 2013) and actual natural environment such as in living plants. A study by Higashikawa et al (2010) suggests that plant-derived LAB are as resistant (or even more resistant) as animal-derived $L A B$ to gastric juices and bile after having found that the strains of Lactobacillus plantarum SN13T and SN35N reached the intestine as compared to animal-derived strains. LAB are found to be prolific in plants, but they remain unexploited. Hence, this work attempted to isolate LAB from 
Isolation and identification of bacteriocin-producing lactic acid

indigenous plants in Mt. Makiling, Los Baños, Laguna, Philippines. As far as we know, this is the first attempt in the country to isolate bacteriocinogenic LAB from wild plants.

\section{MATERIALS AND METHODS}

\section{Isolation of LAB from Plants in Mount Makiling Forest Reserve}

The isolates were obtained from various plants in Mount Makiling Forest Reserve (MMFR) Los Baños, Laguna, Philippines. Trapped or stagnated liquid samples $(0.1 \mathrm{~mL})$ in stems, leaves, and trunks were transferred to a $9.9 \mathrm{~mL}$ de Man Rogosa Sharpe (MRS) broth supplemented with $0.01 \%$ sodium azide which inhibits yeasts. The samples were then incubated anaerobically in a candle jar at $30^{\circ} \mathrm{C}$ for $24 \mathrm{~h}$ in order to minimize growth of aerobic microorganisms and enumerated by serial dilution and pour plating. Each colony of different types was selected and further characterized. Purification of the isolates was performed using MRS medium by successive sub-culturing at $30^{\circ} \mathrm{C}$.

\section{Primary and Secondary Screening for Bacteriocinogenic LAB Isolates}

Direct assay method or deferred assay was used to initially screen for isolates with the ability to produce bacteriocin-like substances (BLS) (Elegado et al 1997). Each isolate was stab-inoculated to MRS Agar and incubated at $30^{\circ} \mathrm{C}$ for $24 \mathrm{~h}$. When growth became visible, the surface of an agar plate was overlaid with $6 \mathrm{~mL}$ MRS soft agar medium ( $0.9 \%$ agar) containing $50 \mu \mathrm{L}$ of approximately $10^{6}$ cells of freshly cultured indicator strains of Leuconostoc mesenteroides, Lactobacillus casei, Enterococcus faecium, Listeria grayi, Bacillus subtilis, Bacillus coagulans and Staphylococcus aureus and then incubated overnight at $37^{\circ} \mathrm{C}$. At the end of the incubation period, the plates were checked for formation of zones of inhibition. Inhibition was scored positive if a clear zone around the colonies of the isolate strains appeared.

For the second screening, only isolates which produced zones of inhibition from direct assay were selected. Isolates were grown in MRS broth and then further subjected for antimicrobial activity screening using the "spot-on-lawn" method as described by Mayr-Harting et al (1972). Cells were separated from the culture broth by centrifugation at $10,000 \mathrm{rpm}$ for $20 \mathrm{~min}$. The cell-free supernatant was adjusted to pH6.5 using $6 \mathrm{~N} \mathrm{NaOH}$ to exclude the effect of organic acids. The supernatant was boiled for $5 \mathrm{~min}$ to destroy heat-labile inhibitory enzymes and proteins (eg, proteases), to inactivate cells and preferentially obtain heat-tolerant bacteriocinlike substances. Complete sterilization was done by passing the supernatant through $0.22 \mathrm{~m}$ membrane filter and diluted serially by two-folds with sterile water. A volume of $10 \mu \mathrm{L}$ was spot inoculated unto a $10 \mathrm{~mL}$ MRS Agar (1.2\%) plate overlaid with $50 \mu \mathrm{L}$ of the selected indicator strain (Enterococcus faecium 79) in $6 \mathrm{~mL}$ soft MRS agar (0.9\%) and then incubated at $37^{\circ} \mathrm{C}$ for $24 \mathrm{~h}$.

\section{Confirmatory Assay for Bacteriocin-like Substances}

Bacteriocin activity was confirmed and quantified by assaying the supernatant treated with Proteinase $\mathrm{K}$ to a final concentration of $1 \mathrm{mg} \mathrm{mL}^{-1}$ and the untreated 
supernatant of the $24 \mathrm{~h}$ old culture of the bacteriocin-producing isolate against indicator strain E. faecium 79 using "spot-on-lawn" method as described previously.

\section{Bacteriocin Assay for Antimicrobial Spectrum}

Ammonium sulfate precipitation of the culture supernatant was done to further concentrate the bacteriocin extract that was used for the antimicrobial spectrum assay of the bacteriocin. Isolate ML 258 was grown in $1 \mathrm{~L}$ modified MRS broth at $37^{\circ} \mathrm{C}$ for $24 \mathrm{~h}$. Cell-free supernatant was obtained by centrifugation at $10,000 \mathrm{rpm}$ for $20 \mathrm{~min}$ at $4^{\circ} \mathrm{C}$. Ammonium sulfate was added to the supernatant with slow stirring in an ice bucket to obtain $50 \%$ saturation and allowed to stand overnight at $4^{\circ} \mathrm{C}$. Protein was precipitated and collected by centrifugation at $10,000 \mathrm{rpm}$ for $20 \mathrm{~min}$ at $4{ }^{\circ} \mathrm{C}$ and dissolved in a small volume of $5 \mathrm{mM}$ phosphate buffer $(\mathrm{pH} 6.5)$. The dissolved precipitate was filter-sterilized and assayed for bacteriocin activity against the indicator strains mentioned above.

\section{Characterization and Identification of LAB Isolates}

The isolate, confirmed to produce bacteriocin after the primary and secondary screening, was characterized and identified based on its morphological, cultural and physiological characteristics along with the use of a rapid identification kit and $16 \mathrm{~S}$ rDNA sequencing. For morphological/cultural and physiological characterization, the isolate was grown in MRS agar and MRS broth. The gram reaction, cell morphology, size and arrangement, spore formation and motility and colonial appearance of the isolate were examined. For the physiological characteristics of the isolate, catalase test, fermentation test (homofermentation or heterofermentation) and oxygen requirement for growth were performed (De Vos et al 2009).

For initial identification, rapid id kit API $50 \mathrm{CHL}$ (BioMerieux, France) was used according to the manufacturer's instructions. API profiles were analyzed using API LAB software (BioMerieux, France). The identity of the bacteriocinogenic LAB isolate was further confirmed through $16 \mathrm{~S}$ rRNA gene sequencing and through homology search from the National Center for Biotechnology Information (NCBI) database using the Basic Local Alignment Search Tool (BLAST) program.

\section{DNA Isolation and PCR Amplification}

Genomic DNA was isolated using the Cetylmethyl Ammonium Bromide (CTAB) method and the chloroform isoamyl alcohol (24:1) treatment, respectively, as described by Moore (1993). DNA was then precipitated by adding 1/10 volume of sodium acetate (1M, pH4.5) followed by the addition of two volumes of chilled $95 \%$ ethanol. The DNA pellets were washed with $70 \%$ ethanol and air-dried. It was then dissolved in $50 \mu \mathrm{L}$ of $10 \mathrm{mM}$, pH8 Tris-EDTA (TE) buffer and loaded on $0.8 \%$ agarose gel with 1 XTAE buffer to check for its integrity. The nucleic acid in gel was analyzed after electrophoresis at $50 \mathrm{~V}$ with constant temperature of $40^{\circ} \mathrm{C}$ using Mupid-2 Mini Gel Electrophoresis Unit (Cosmo Bio Co., Ltd, Japan) and then stained with ethidium bromide $\left(0.5 \mu \mathrm{g} \mathrm{mL}^{-1}\right)$ for $10 \mathrm{~min}$ and visualized using the UV Transilluminator and Gel Documentation System (Labworks, UVP, Inc., CA, USA). 
Isolation and identification of bacteriocin-producing lactic acid

PCR amplification of the 16S rRNA gene was performed using primers $1101 \mathrm{~F}$ (5'-AAC GAG CGC AAC CC-3') and 1407R (5'-GAC GGG CGG TGT GTA C-3') (Kawamura et al 1995, Elegado et al 2001). One microliter $(1 \mu \mathrm{L})$ of the isolated DNA was subjected to PCR in a $15 \mu \mathrm{L}$ reaction mixture consisting of $0.5 \mu \mathrm{L}$ of each of the forward and reverse primers and $13 \mu \mathrm{L}$ of the Platinum PCR Supermix High Fidelity (Invitrogen) containing $22 \mathrm{U} \mathrm{\textrm {mL } ^ { - 1 }}$ recombinant Taq DNA polymerase from Pyrococcus species GB-D and Platinum Taq Antibody; 66mM Tris- $\mathrm{SO}_{4}$ (pH8.9); $19.8 \mathrm{mM}_{\left(\mathrm{NH}_{4}\right)_{2} \mathrm{SO}_{4} ; 2.4 \mathrm{mM} \mathrm{MgSO}} ; 220 \mu \mathrm{M}$ dNTPs; and stabilizers. Amplification reaction was carried out with primary DNA denaturation step of $94^{\circ} \mathrm{C}$ for $5 \mathrm{~min}$ followed by 30 cycles of $1 \mathrm{~min}$ at $94^{\circ} \mathrm{C}, 20 \mathrm{~s}$ at $52^{\circ} \mathrm{C}$, and $1 \mathrm{~min}$ and $30 \mathrm{~s}$ at $72^{\circ} \mathrm{C}$. The final extension was done for $7 \mathrm{~min}$ at $72^{\circ} \mathrm{C}$. After amplification, $5 \mu \mathrm{L}$ of PCR products were electrophoresed, stained with ethidium bromide and visualized as above. Homology search from the National Center for Biotechnology Information (NCBI) database using the Basic Local Alignment Search Tool (BLAST) program was done. For sequence assembly and alignment, MEGA 5 software program was used. The sequence information of the isolate was then compared to sequences from different types of bacterial strains held in gene data system and the phylogenetic trees were constructed using the neighbor-joining method. The topologies of trees were evaluated by bootstrap analysis of the sequence data with MEGA 5 software based on 1000 random resamplings.

\section{RESULTS AND DISCUSSION}

\section{Isolation of Lactic Acid Bacteria}

A total of 63 lactic acid bacteria (LAB) were isolated from different plants located in different altitudes of Mount Makiling Forest Reserve (MMFR). Table 1 shows the sources, the number of isolates in each source and the altitudes from where these isolates were obtained.

Table 1. Sources and number of isolates obtained from different altitudes of Mount Makiling Forest Reserve

\begin{tabular}{lcc}
\hline \multicolumn{1}{c}{ Source } & Altitude (feet) & Number of Isolates \\
\hline Tree trunk (unidentified) & 650 & 4 \\
Sandoricum koetjape & 650 & 5 \\
Costus speciosus & 650 & 4 \\
Decaying log (unidentified) & 650 & 6 \\
Polysticus & 980 & 3 \\
Asplenium nidus cv. & 980 & 3 \\
Microsorum longissimus Fée & 980 & 3 \\
Philodendron scandens & 1,300 & 10 \\
subsp. oxycardium & & \\
Colocasia esculenta Linn. & 1,300 & 5 \\
Musa sp. & 2,300 & 5 \\
Philodendron speciosum & 2,600 & 5 \\
Panicaum maximum & 3,280 & 5 \\
Pandamus odoratissimus & 3,280 & 5 \\
& & 63 \\
\hline
\end{tabular}


In this study, $L A B$ were found prolific in plants from MMFR. As to our knowledge, this is the first isolation of $L A B$ in this forest reserve. $L A B$ are fastidious and require complex nutritional requirement. However, the presence of these bacteria from stagnant water in different plant parts showed that nutrients are readily available to support growth of LAB in plants. One possible source of nutrients such as carbohydrates, amino acids, fatty acids, salt, vitamins and derivatives of nucleic acids needed by these bacteria comes from the plant itself. Plants are composed of carbohydrates, amino acids, vitamins etc. that could have become available and used as substrate by LAB when the plants were physically cut or scratched by animals and insects. Moreover, abundance of leaf litter from tall trees, decaying fruits and logs, nectar from flowers and remains of insects may have also enabled LAB to thrive in this kind of habitat.

Aside from the available soluble nutrients in plants, other factors attributed to their wide distribution and successful establishment were the conditions in MMFR. The low oxygen tension due to high altitude, the varying temperature, and the humidity of this area were presumed to favor growth of LAB. Furthermore, LAB are also capable of producing metabolites inhibitory to other organisms, thus enabling them to occupy and establish a niche and eliminate competition among the other microflora of the MMFR.

There are also various authors who isolated $L A B$ from plants as reported in several publications. As early as 1968, Mundt and Hammer found different Lactobacillus species in plants such as $L$. plantarum, $L$. fermentum and small number of $L$. brevis, L. casei, L. viridescens, L. cellobiosus and L. salivarius (Mundt \& Hammer 1968). Another lactic acid bacteria, Lactococcus lactis ssp. lactis, has been found by Salama et al (1995) from trees such as Lamium purpureum (red nettle), Sonchus oleraceus (common sow thistle), Rubus discolor (Himayan blackberry) and Solanum nigrum (black nightshade). They also reported presence of $L$. lactis ssp. lactis on vegetables such as sweet pea, potato, cucumber, bean, cantaloupe, broccoli and corn.

\section{Primary and Secondary Screening of Bacteriocin-producing LAB}

In the primary screening, 13 out of the 63 pure isolates produced zone of inhibition to lawn of various bacterial indicators as presented in Table 2 which is about nineteen percent (19\%) of the total isolates obtained. This inhibition was due possibly to organic acids (primarily lactic acid), enzymes, hydrogen peroxide, bacteriocin-like substances, or other metabolic by-products that these LAB may have produced. Martirosyan et al (2004), in their study of sour milk products Narine, Karine and Matsun, revealed that the antimicrobial activity of these milk products against 16 pathogenic microbes, which include $S$. aureus, E. coli and S. flexneri, was related to the presence of high amount of L-lactic acid and of sodium and calcium salts produced by $L$. acidophilus. Moreover, the lactic acid, in addition to its antimicrobial property due to lowering of the $\mathrm{pH}$, was reported by Alakomi et al (2000) to be capable of permeabilizing gram-negative bacteria (ie, S. typhimurium, $P$. aeruginosa, E. coli) by disrupting their outer membrane and subsequently act as potentiator of the effects of the other antimicrobial substances such as antibiotics, enzymes and bacteriocins. 
Isolation and identification of bacteriocin-producing lactic acid

For the LAB indicator strains (L. mesenteroides, E. faecium and L. casei) used in the experiment, resistance to the effects of lactic acid was already expected, for they can tolerate acidic $\mathrm{pH}$ at certain level. Thus, it was presumed that other substances, aside from lactic acid, must be present leading to the inhibition of these indicator organisms. As mentioned earlier, one possible explanation for the inhibition was the presence of bacteriocin-like substances which have antimicrobial activity against gram-positive bacteria and to the closely related species of the producing strain.

For the second screening, the cell-free supernatant of the isolates which produced zone of inhibition during the primary screening was neutralized, filtersterilized, and boiled for $5 \mathrm{~min}$. Boiling of the cell-free supernatant was performed to detect for the presence of bacteriocins belonging to Class II type which are known to be heat stable (Ennahar et al 2000). This was also employed to inactivate the proteolytic enzymes such as proteases released by the isolates in the medium which may degrade the proteinaceous bacteriocins.

Table 2. Inhibition of various indicator organisms by lactic acid bacteria isolates from plants of Makiling Forest Reserve

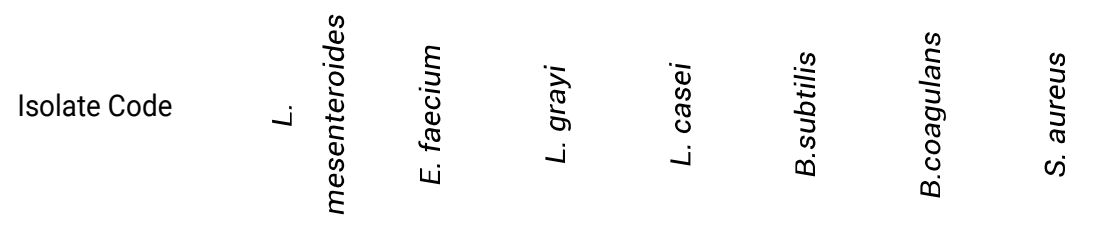

\begin{tabular}{|c|c|c|c|c|c|c|c|}
\hline 1 & - & - & - & - & ++ & ++ & - \\
\hline 19 & ++ & ++ & - & - & - & - & - \\
\hline 20 & - & + & - & - & - & + & + \\
\hline 23 & - & ++ & + & + & - & - & - \\
\hline 35 & ++ & ++ & ++ & ++ & ++ & ++ & ++ \\
\hline 39 & - & - & + & - & - & - & - \\
\hline 51 & - & - & + & - & - & - & - \\
\hline 72 & + & + & ++ & + & - & - & - \\
\hline 80 & ++ & ++ & ++ & + & - & - & - \\
\hline 501 & + & ++ & ++ & - & - & - & - \\
\hline 258 & - & + & ++ & - & ++ & ++ & ++ \\
\hline 530 & - & + & + & - & ++ & + & + \\
\hline 532 & - & - & - & - & ++ & ++ & - \\
\hline
\end{tabular}

Legend: $+=<2.5 \mathrm{~mm}$ diameter zone of inhibition; $++=>2.5 \mathrm{~mm}$ diameter zone of inhibition 
Among the isolates with activity against the different indicators, only the isolate from a fern designated as ML 258 gave a positive result for bacteriocin-like substance (BLS). This bacteriocin-like substance was observed when the neutralized, filter-sterilized and boiled cell-free supernatant was spotted on a lawn of E. faecium 79 as described earlier. However, it is possible that the other isolates produced BLS not belonging to class II which were heat sensitive; hence, these were destroyed during the heating process. Moreover, factors such as method of detection, selection of indicator organisms and media may have also influenced the results of the assay. Furthermore, the choice of indicator organism used in the screening is also extremely important because if the selected indicator is resistant to the bacteriocin being tested, no antimicrobial activity will be detected.

To confirm whether the BLS produced by the selected isolate was really bacteriocin, cell-free supernatant without and with added enzyme Proteinase K was spotted on lawn of the same isolate and of $E$. faecium as the indicator organisms, respectively. This was performed to determine if the BLS has activity against its producer and if it was degraded by the enzyme.

\section{Confirmatory Test for Bacteriocin}

The results obtained confirmed that the substance with antimicrobial activity present in the supernatant was indeed bacteriocin. In the supernatant treated with proteolytic enzyme Proteinase $K$, loss of activity against $E$. faecium was observed. Likewise, no activity was detected when the supernatant was spotted on lawn of the producing isolate. Both observations met the criteria of Konisky (1982) that led to the conclusion that there are only two true requisites for a substance to be called bacteriocin. One criterion is that bacteriocin should be proteinaceous in nature while the other was the lack of lethality to the cells that produce them.

\section{Antimicrobial Spectrum of Ammonium Sulfate Precipitate}

The antimicrobial spectrum of the ammonium sulfate precipitate of the crude extract of bacteriocin is presented in Table 3 . The precipitate of crude extract of bacteriocin exhibited a very narrow range of inhibitory activity against the selected Gram-negative (10 strains) and Gram-positive (10 strains) bacterial species. Among the 20 species tested, only Enterococcus faecium and Lactobacillus acidophilus showed strong sensitivity to the bacteriocin with zones of inhibition of $20 \mathrm{~mm}$ and $16.5 \mathrm{~mm}$, respectively. No antagonism, however, was observed for the Gram-negative and some Gram-positive bacterial species used as test organisms. It was expected that Gram-negative bacteria would not be inhibited since bacteriocins produced by $L A B$ are generally active only towards Gram-positive bacteria (Klaenhammer 1988). The narrow spectrum of bacteriocin activity obtained from the isolate ML 258 is common among Carnobacterium as reported by different authors. Schillinger et al (1993) characterized the bacteriocin of $C$. piscicola LV 61 and found to have activity against Carnobacterium, Enterococcus and Listeria. Piscicocin produced by C. piscicola CS526, on the other hand, was also found by Yamazaki et al (2005) to inhibit strains of Enterococcus and Listeria but with antagonism as well to strains of Pediococcus and Leuconostoc. It is surprising, however, that the crude extract of bacteriocin produced by ML 258 
Isolation and identification of bacteriocin-producing lactic acid

isolate did not have any activity against Listeria monocytogenes, a bacterium known to be sensitive to bacteriocins produced by Carnobacterium species as reported in several literatures.

The absence of the activity of the isolate's bacteriocin against this species of bacterium could not be elucidated. It was first suspected that the gene responsible for bacteriocin production is plasmid-borne and the subsequent transfer of the culture may have resulted in loss of the plasmid. Another possibility is the resistance of the particular strain of L. monocytogenes used as bacteriocin activity is also known as strain dependent. However, when the precipitate was spotted on lawn of E. faecium, large zone of inhibition was detected. Hence, this only confirmed that the bacteriocin was still present but with no antimicrobial activity against $L$. monocytogenes, although inhibition was observed in direct or deferred assay which may be due to the presence of lactic acid or enzymes produced by this isolate and not due to bacteriocin.

Table 3. Antimicrobial spectrum of ammonium sulfate precipitate of isolate ML 258

\begin{tabular}{|c|c|c|c|}
\hline \multirow{2}{*}{ Source } & \multirow{2}{*}{ Scientific Name } & \multicolumn{2}{|c|}{ Presence of Inhibition Zone } \\
\hline & & Direct Assay & $\left(\mathrm{NH}_{4}\right)_{2} \mathrm{SO}_{4}$ precipitate \\
\hline IBS, UPLB & Bacillus cereus & + & - \\
\hline BIOTECH, UPLB & Bacillus subtilis & + & - \\
\hline IBS, UPLB & Enterobacter cloacae & - & - \\
\hline IBS, UPLB & Enterobacter sakazeki & + & - \\
\hline IBS, UPLB & Enterococcus faecium & + & +++ \\
\hline IBS, UPLB & Esherichia coli & + & - \\
\hline BIOTECH, UPLB & Lactobacillus acidophilus & + & +++ \\
\hline BIOTECH, UPLB & Lactobacillus casei & - & - \\
\hline IBS, UPLB & Lactobacillus paracasei & + & - \\
\hline IBS, UPLB & Lactobacillus plantarum & + & - \\
\hline IBS, UPLB & Lactobacillus rhamnosus & + & - \\
\hline BIOTECH, UPLB & Leuconostoc mesenteroides & + & - \\
\hline BIOTECH, UPLB & Listeria monocytogenes & + & - \\
\hline BIOTECH, UPLB & Listeria grayi & + & - \\
\hline BIOTECH, UPLB & Micrococcus luteus & + & - \\
\hline BIOTECH, UPLB & Pediococcus pentosaceus & - & - \\
\hline BIOTECH, UPLB & Pediococcus acidilactici & + & - \\
\hline IBS, UPLB & Pediococcus cerevisiae & + & - \\
\hline IBS, UPLB & Pseudomonas aeruginosa & + & - \\
\hline BIOTECH, UPLB & Salmonella typhimurium & + & - \\
\hline BIOTECH, UPLB & Staphylococcus aureus & + & - \\
\hline
\end{tabular}

Legend: $+=<2.5 \mathrm{~mm} ;++=>2.5-10.0 \mathrm{~mm} ;+++=>10.0 \mathrm{~mm}$ diameter zones of inhibition 
Lat, Elegado \& Dalmacio

\section{Characterization and Identification of LAB Isolate}

Morphological / cultural and physiological characteristics of the isolate. ML 258 isolate was gram-positive short rods which occur singly, in pairs or in chains. Cells were non-motile and non-spore forming. In MRS agar plate, colonies were circular with shiny and smooth surface, convex with entire margin, yellowish in color and approximately $1 \mathrm{~mm}$ in diameter. Physiologically, ML 258 isolate was negative for catalase, microaerophilic and has a heterofermentative type of fermentation.

Identification using rapid test kit. The pure isolate of ML 258, using the API 50 $\mathrm{CHL}$ kits, was identified as Carnobacterium piscicola with a good identification remark of $97.7 \%$ on the basis of the carbohydrates it can metabolize. The positive results, as indicated by the change in color of the indicator due to decrease in $\mathrm{pH}$, revealed the biochemical profile of the isolate which was used as reference by the software with database provided by the manufacturer in identifying the isolate. Twenty out of 49 carbohydrates were metabolized by the isolate which include glycerol, ribose, galactose, glucose, fructose, mannose, lactose, and mannitol (Table 4). These results, together with the morphological and physiological characteristics, were used in the identification of the isolate.

16S rRNA sequencing and homology analysis. Results of the PCR amplification of the fragment of the 16S rRNA genes of ML 258 showed a 300bp PCR product which was amplified using the primers $1101 \mathrm{~F}$ and 1407R as shown in Figure1.

Table 4. Acid production of isolate ML 258 from fermentation of different carbohydrates

\begin{tabular}{|c|c|c|c|c|c|c|c|}
\hline \multicolumn{2}{|c|}{ Carbohydrates } & \multirow{2}{*}{$\begin{array}{l}\text { Code } \\
\text { Control }\end{array}$} & \multirow{2}{*}{$\begin{array}{c}\text { Results } \\
-\end{array}$} & \multicolumn{2}{|c|}{ Carbohydrates } & \multirow{2}{*}{$\begin{array}{l}\text { Code } \\
\text { ESC }\end{array}$} & \multirow{2}{*}{$\frac{\text { Results }}{+}$} \\
\hline 0 & Control & & & 25 & Esculine & & \\
\hline 1 & Glycerol & GLY & + & 26 & Salicine & SAL & + \\
\hline 2 & Erythritol & ERY & - & 27 & Cellobiose & CEL & + \\
\hline 3 & D-arabinose & DARA & - & 28 & Maltose & MAL & + \\
\hline 4 & L-arabinose & LARA & - & 29 & Lactose & LAC & + \\
\hline 5 & Ribose & $\mathrm{RIB}$ & + & 30 & Melibiose & MEL & - \\
\hline 6 & D-xylose & D-XYL & - & 31 & Saccharose & S & + \\
\hline 7 & L-xylose & L-XYL & - & 32 & Trehalose & TRE & + \\
\hline 8 & Adonitol & ADO & - & 33 & Inuline & INU & - \\
\hline 9 & b-Methyl-xyloside & BMDX & - & 34 & Melezitose & MLZ & - \\
\hline 10 & Galactose & $\mathrm{GAL}$ & + & 35 & D-raffinose & RAF & - \\
\hline 11 & D-glucose & GLU & + & 36 & Amidon & S & - \\
\hline 12 & D-fructose & FRU & + & 37 & Glycogene & GLYG & - \\
\hline 13 & D-mannose & MNE & + & 38 & Xylitol & XLT & - \\
\hline 14 & L-sorbose & SBE & - & 39 & b-Gentibiose & GEN & + \\
\hline 15 & Rhamnose & RHA & - & 40 & D-Turanose & DTUR & - \\
\hline 16 & Dulcitol & DUL & - & 41 & D-Lyxoe & DLYX & - \\
\hline 17 & Inositol & INO & - & 42 & D-Tagatose & DTAG & - \\
\hline 18 & Mannitol & MAN & + & 43 & D-Fucose & DFUC & - \\
\hline 19 & Sorbitol & SOR & - & 44 & L-Fucose & LFUC & - \\
\hline 20 & a-Methyl-D-Mannose & AMDM & + & 45 & D-Arabitol & DAR & - \\
\hline 21 & a-Methyl-D-Glucoside & AMDG & - & 46 & L-Arabitol & LAR & - \\
\hline 22 & $\mathrm{~N}$-acetyl glucosamine & NAG & + & 47 & Gluconate & GNT & + \\
\hline 23 & Amygdaline & AMY & + & 48 & 2-keto-gluconate & $2 K G$ & - \\
\hline 24 & Arbutine & ARB & + & 49 & 5-keto-gluconate & $5 K G$ & - \\
\hline
\end{tabular}


Isolation and identification of bacteriocin-producing lactic acid

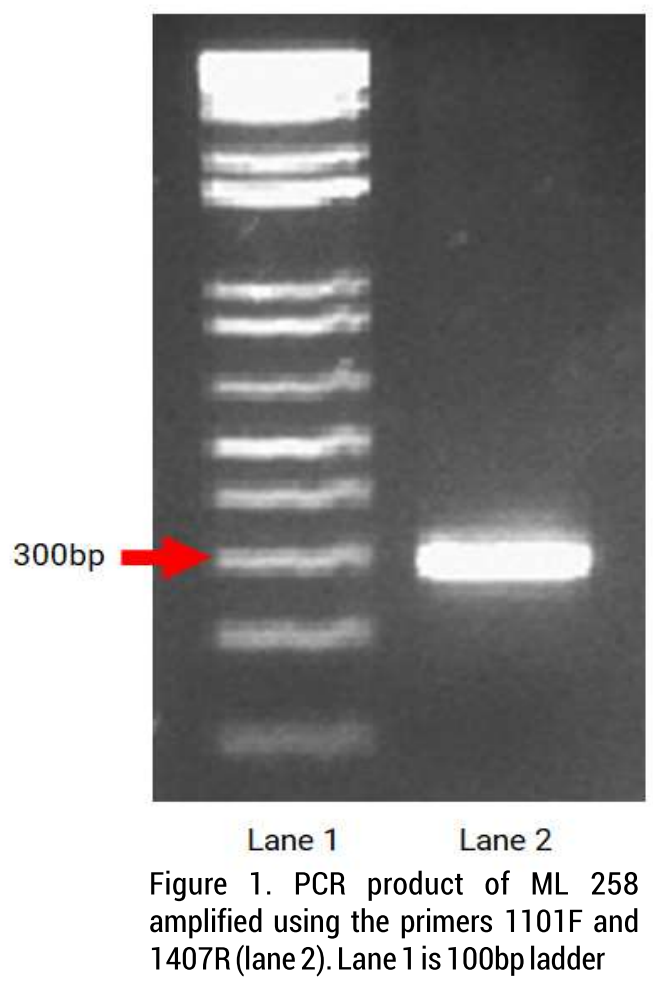

By sequence analysis, BLAST hits were recorded for the forward and reverse primers used. The result demonstrates that the sequence is most similar to Carnobacterium maltaromaticum with a maximum identification of $95 \%$ and $93 \%$ for forward and reverse primers, respectively. However, according to Roselló and Amman (2001), standardization of a species corresponds with approximately $97 \%$ rDNA similarity although they have also cautioned that a species should not be solely distinguished based on rRNA or rDNA sequence information. On the other hand, Zoetendal et al (2004) discussed that if the sequence similarity is anywhere between 95 and $99 \%$ it is considered as the same species. On the contrary, according to Tajima et al (1999) there are no exact 16S rDNA similarity limits for defining specific taxa such as genus and species; in general, species definition requires sequence similarities greater than $98 \%$.

Tajima et al (1999) cited that phylogenetic clustering of bacterial groups, rather than similarity value, should be used as a guide for defining bacterial taxa. For phylogenetic analysis of isolate ML 258, a total of 25 sequences were considered for phylogenetic analysis to clarify their taxonomic position based on neighborjoining methods. Twenty-four conserved $16 \mathrm{~S}$ ribosomal DNA sequences of known microorganisms were downloaded using BLAST to perform sequence comparisons. Multiple sequence alignment of the known microorganisms and of the unknown sequences was carried out using the ClustalW alignment function of MEGA and phylogenetic tree was constructed using the neighbor-joining function of the same software. Results revealed as shown in Figure 2 that isolate ML 258 (IS258-1407) was more similar to the genus Enterococcus sp. 
Lat, Elegado \& Dalmacio

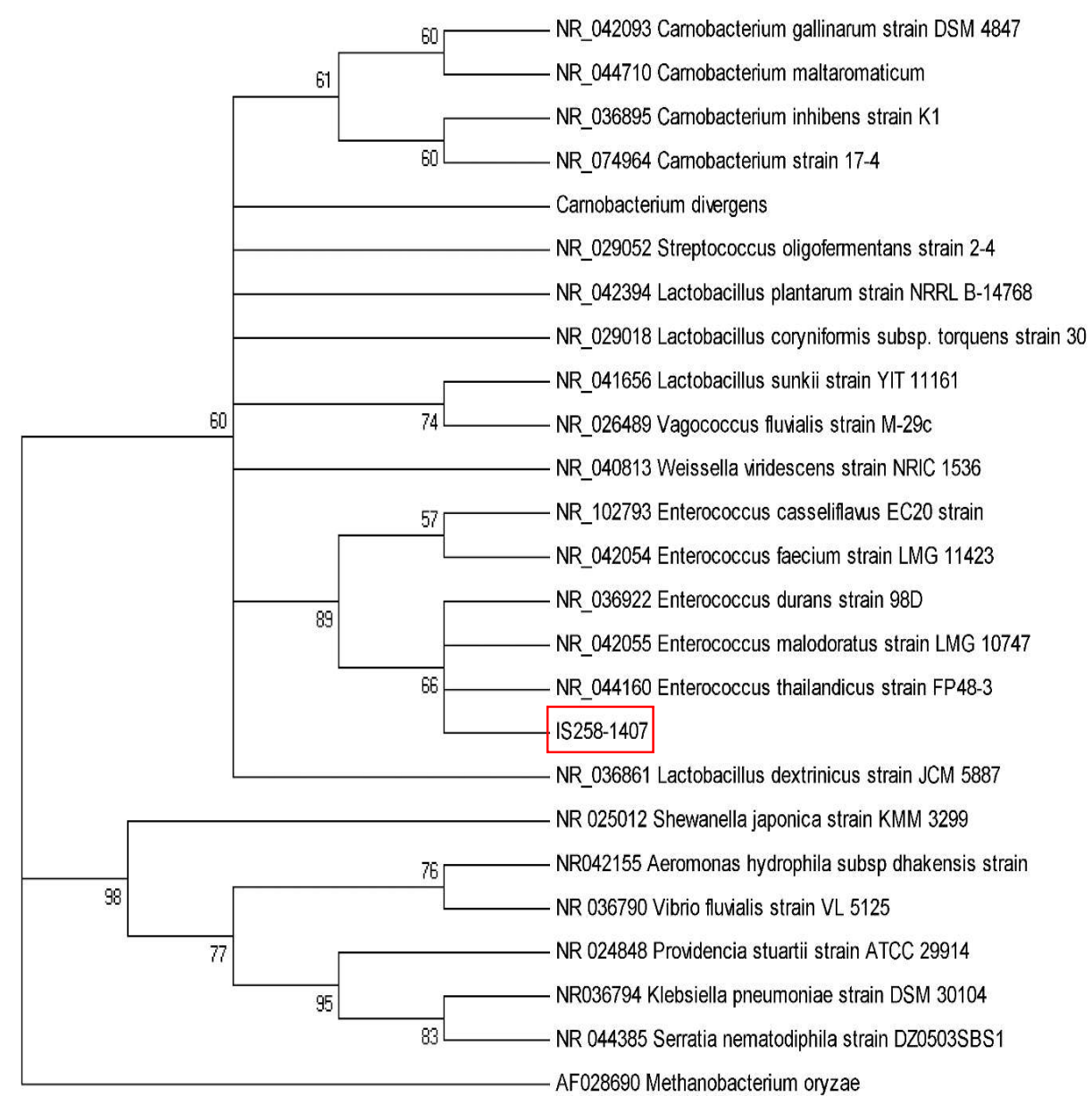

Figure 2. Molecular Phylogenetic analysis by Maximum Likelihood method

The evolutionary history was inferred by using the Maximum Likelihood method based on the Tamura-Nei model (Tamura et al 1993) The bootstrap consensus tree inferred from 1000 replicates (Felsenstein $\mathrm{J} \mathrm{1985)}$ is taken to represent the evolutionary history of the taxa analyzed (Felsenstein $\mathrm{J}$ 1985). Branches corresponding to partitions reproduced in less than $50 \%$ bootstrap replicates are collapsed. The percentage of replicate trees in which the associated taxa clustered together in the bootstrap test (1000 replicates) are shown next to the branches (Felsenstein J 1985). Initial tree(s) for the heuristic search were obtained automatically as follows. When the number of common sites was $<100$ or less than one fourth of the total number of sites, the maximum parsimony method was used; otherwise BIONJ method with MCL distance matrix was used. The analysis involved 25 nucleotide sequences. Codon positions included were $1 \mathrm{st}+2 \mathrm{nd}+3 \mathrm{rd}+$ Noncoding. All positions with less than $80 \%$ site coverage were eliminated. That is, fewer than $20 \%$ alignment gaps, missing data, and ambiguous bases were allowed at any position. There were a total of 200 positions in the final dataset. Evolutionary analyses were conducted in MEGA5 (Tamura et al 2011). 
Isolation and identification of bacteriocin-producing lactic acid

\section{SUMMARY AND CONCLUSION}

Lactic acid bacteria were isolated from plants in different altitudes of Mount Makiling Forest Reserve, Los Banos, Laguna, Philippines (MMFR), 13 of which showed antagonism versus $L$. mesenteroides, E. faecium, $L$. grayi, $B$. subtilis, $B$. coagulans and $S$. aureus through direct assay. However, only one isolate from a fern, designated as ML 258, was found to have bacteriocin-like activity against the indicator strain E. faecium 79. ML 258 was morphologically, culturally and physiologically typical of lactic acid bacteria. Using the API $50 \mathrm{CHL}$ kit, it was identified as Carnobacterium piscicola (98\%), but 16S rRNA gene sequencing and homology search from NCBI gene bank using the BLAST program revealed $93-95 \%$ similarity to $C$. maltaromaticum. Moreover, after phylogenetic analysis, the isolate was found more similar with Enterococcus sp. although its morphology showed otherwise. Full characterization of the bacteriocin after thorough purification should be the next steps to further elucidate this bacteriocinogenic lactic acid bacteria. This work also proposes that for a thorough identification of isolates, further molecular characterization like DNA-DNA hybridization and DNA fingerprinting using housekeeping genes and other conserved genes are needed.

\section{REFERENCES}

Alakomi HL, Skytta E, Saarela M, Mattila-Sandholm T, Latva-Kala K \& Helander IM. 2000. Lactic acid permeabilizes gram-negative bacteria by disrupting the outer membrane. Applied Environmental Microbiology 66(5):2001-2005

Axelsson LT. 2004. Lactic acid bacteria: classification and physiology. In Salminen S, Wright AV \& Ouwehand A (eds) Lactic Acid Bacteria - Microbiology and Functional Aspects (pp1-67). New York: Marcel Dekker, Inc

Banaay CGB, Balolong MP \& Elegado FB. 2013. Lactic acid bacteria in Philippine traditional fermented foods. In Kongo M (ed) Lactic Acid Bacteria - R\&D for Food, Health and Livestock Purposes (pp571-588)

Camplice E and Fitzgerald GF. 1999. Food fermentations: Role of microorganisms in food production and preservation. International Journal of Food Microbiology 50(1-2):131-149

De Vos P, Garrity G, Jones D, Krieg NR, Ludwig W, Rainy FA, Schleifer K-H \& Whitman WB. 2009. Bergey's Manual of Systematic Bacteriology: Volume 3: The Firmicutes (pp549). Springer

Elegado FB, Nakayama J \& Sonomoto K. 2001. Identification of bacteriocinogenic lactic acid bacteria isolated from Philippine fermented foods through 16S rRNA gene sequence analysis. Philippine Journal of Biotechnology 12(1-2):33-40

Elegado FB, Kim WJ \& Kwon DY. 1997. Rapid purification, partial characterization and antimicrobial spectrum of the bacteriocin, Pediocin AcM, from Pediococcus acidilactici M. International Journal of Food Microbiology 37:111

Ennahar S, Sashihara T, Sonomoto K \& Ishizaki A. 2000. Class Ila bacteriocins: biosynthesis, structure and activity. FEMS Microbiology Review 24(1): 85-106

Felsenstein J. 1985. Confidence limits on phylogenies: An approach using the bootstrap. Evolution 39:783-791 
Lat, Elegado \& Dalmacio

Fijan S. 2016. Antimicrobial effect of probiotics against common pathogens. In Rao $V$ and Rao LG (eds) Probiotics and Prebiotics in Human Nutrition and Health. DOI: $10.5772 / 61495$

Halász A. 2009. Lactic acid bacteria. Food Quality and Standards 3:70-82

Higashikawa F, Noda M, Awaya T, Nomura K, Oku H \& Sugiyama M. 2010. Improvement of constipation and liver function by plant-derived lactic acid bacteria: a double-blind, randomized trial. Nutrition 26(4):367-374

Kawamura Y, Hou XG, Sultana F, Miura H \& Ezaki T. 1995. Determination of $16 \mathrm{~S}$ rRNA sequences of Streptococcus mitis and Streptococcus gordonii and phylogenetic relationships among members of the genus Streptococcus. International Journal of Systematic Bacteriology 45:406-408

Konisky J. 1982. Colicins and other bacteriocins with established modes of action. Annual Review of Microbiology 36:125-44

Martirosyan AO, Mndzhoyan SHL, Charyan LM, Kopyan LG \& Nikishchenko MN. 2004. Antimicrobial activity of lactic acid bacteria from sour milk products narine, karine, and matsun. Applied Biochemistry and Microbiology 40(2): 178-180

Mayr-Harting A, Hedges AJ \& Berkeley RCW. 1972. Methods for studying bacteriocins. In Norris JR and Ribbons DW (eds) Methods in Microbiology (pp315-422). New York: Academic Press.

Mora D, Scarpellini M, Franzetti L, Colombo S \& Galli A. 2003. Reclassification of Lactobacillus maltaromicus (Millet et al 1974) DSM 2034T and DSM 20344 and Carnobacterium piscicola (Collins et al 1987) DSM 20730 and DSM 20722 as Carnobacterium maltaromaticum comb. nov. International Journal of Systematic and Evolutionary Microbiology 53:675-678

Mundt JO and Hammer JL. 1968. Lactobacilli on plants. Applied Microbiology 16:1326-1330

Narvhus JA and Axelsson L. 2003. Lactic acid bacteria. In Caballero B, Trugo L \& Finglas PM (eds) Encyclopedia of Food Sciences and Nutrition (2nd edn) (pp3463-3472). Academic Press (Copyright Elsevier Sci. Ltd.)

Perez RH, Perez MTM \& Elegado FB. 2015. Bacteriocins from lactic acid bacteria: biosynthesis, mode of action, fermentative production, uses and prospects. International Journal of Philippine Science and Technology (formerly Philippine Science Letters) 8(2):61-67

Rosselló-Mora R and Amman R. 2001. The species concept for prokaryotes. FEMS Microbiology Review 25(1):39-67

Salama MS, Musafija-Jeknic T, Sandine WE \& Giovannoni SJ. 1995. An ecological study of lactic acid bacteria: isolation of new strains of Lactococcus including Lactococcus lactis subspecies cremoris. Journal of Dairy Science 78(5):1004-1017

Schillinger U, Stiles ME \& Holzapfel WH. 1993. Bacteriocin production by Carnobacterium piscicola LV 61. International Journal of Food Microbiology 20(3):131-147

Tajima K, Aminov RI, Nagamine T, Ogata K \& Nakamura M. 1999. Rumen bacterial diversity as determined by sequence analysis of $16 \mathrm{~S}$ rDNA libraries. FEMS Microbiology Ecology 29(2):159-169

Wilson K. 1990. Preparation of genomic DNA from bacteria. In Ausubel FM, Brent R, Kingston RE, Moore DD, Smith JE, Seidman JG \& Struhl K (eds) Current Protocols in Molecular Biology (pp2.4.1-2.4.2). John Wiley and Sons, Inc 
Isolation and identification of bacteriocin-producing lactic acid

Woraprayote W, Malila Y, Sorapukdee S, Swetwiwathana A, Benjakul S \& Visessanguan W. 2016. Bacteriocins from lactic acid bacteria and their application in meat and meat products. Meat Science 120:118-132

Yamazaki K, Suzuki M, Kawai Y, Inoue N \& Montville TJ. 2005. Purification and characterization of a novel class Ila bacteriocin, Piscicocin cs526, from surimiassociated Carnobacterium piscicola CS526. Applied Environmental Microbiology 71(1):554-557

Yang S, Lin C, Sung CT \& Fang J. 2014. Antibacterial activities of bacteriocins: application in foods and pharmaceuticals. Frontiers in Microbiology 5(241):110

Yerlikaya 0. 2014. Starter cultures used in probiotic dairy product preparation and popular probiotic dairy drinks. Food Science and Technology (Campinas) 34(2):221-229

Zacharof MP and Lovitt RW. 2012. Bacteriocins produced by lactic acid bacteria: a review article. APCBEE Procedia 2(2):50-56

Zoetendal EG, Collier CT, Koike S, Mackie RI \& Gaskins RH. 2004. Molecular ecological analysis of the gastrointestinal microbiota: a review. Journal of Nutrition 134(2):465-472 